\title{
Neurotrophin-4/5 Enhances Survival of Cultured Spiral Ganglion Neurons and Protects Them from Cisplatin Neurotoxicity
}

\author{
J. Lisa Zheng, ${ }^{1}$ Randall R. Stewart, ${ }^{2}$ and Wei-Qiang Gao' \\ 'Department of Neuroscience, Genentech, Inc., South San Francisco, California 94080 and ${ }^{2}$ Department of \\ Anatomy, George Washington University Medical Center, Washington, D.C. 20037
}

\begin{abstract}
Destruction of spiral ganglion neurons (SGNs) induced by injury and toxins is one of the major causes for hearing loss. Here we report that neurotrophin-4/5 (NT-4/5), a member of the nerve growth factor family, promoted survival of postnatal rat SGNs up to threefold in dissociated cell cultures. The survival-promoting potency of NT-4/5 was equivalent to that of BDNF and stronger than that of NT-3. In contrast, NGF showed no detectable effects. Immunohistochemistry, with TrkB and TrkA antisera, revealed that these neurons produced TrkB proteln, the functlonal receptor for NT-4/5 and BDNF, but not TrkA protein, the highaffinity receptor for NGF. The survival-promoting activity of NT-4/5 was completely inhibited by TrkB-IgG fusion protein. These results suggest that NT-4/5 is a specific survival factor for SGNs. In addition, NT-4/5 protected the SGNs from neurotoxic effects of the anti-cancer drug, cisplatin. Thus, NT-4/5 may have therapeutic value in preventing hearing impairment caused by damage to primary auditory afferent neurons.
\end{abstract}

[Key words: neurotrophin-4/5, brain-derived neurotrophic factor, neurotrophin-3, nerve growth factor, spiral ganglion neurons, cochlear, auditory, cisplatin, ototoxicity, hearing impairment, TrkB immunohistochemistry, P75, TrkB-IgG, TrkC-IgG]

Spiral ganglion neurons (SGNs) are primary auditory afferent neurons that deliver signals from the peripheral auditory receptors, the hair cells in the organ of Corti, to the brain through the cochlear nerve. Damage or loss of either the SGNs or the hair cells can affect the auditory pathway and result in hearing impairments. In general, hearing disorders can be caused by infections, mechanical injury, chemicals, loud sounds, aging, and clinical drugs such as the chemotherapeutic agent, cisplatin (Fleischman et al., 1975; Stadnicki et al., 1975; Dublin, 1976; Nakai et al., 1982; Hood and Berlin, 1986). Some hearing impairments are neuron mediated, some are hair cell mediated, and others are induced by damage to both auditory ncurons and hair cells. Since hearing impairment is a serious affliction, any agent

\footnotetext{
Received Jan. 12, 1995; revised Feb. 28, 1995; accepted Mar. 3, 1995.

We are grateful to Dr. Franz Hefti for his inspiration and valuable suggestions and Dr. Arnon Rosenthal for helpful discussions. We also thank David Shelton for providing TrkB-IgG and TrkC-IgG fusion proteins, Dr. Stuart Feinstein and Dr. Monte Radeke for TrkB antiserum, and Dr. Douglas Clary and Louis Reichardt for TrkA and P75 antibodies.

Correspondence should be addressed to Dr. Wei-Qiang Gao, Department of Neuroscience, MS \#72, Genentech, Inc., 460 Point San Bruno Boulevard, South San Francisco, CA 94080.

Copyright $(1995$ Society for Neuroscience 0270-6474/95/155079-09\$05.00/0
}

that can protect the auditory neurons and/or hair cells from damage would be of great benefit.

Neurotrophic factors are good candidate molecules for prevention of neuron-mediated hearing impairments, as they have been widely shown to regulate neuronal differentiation and survival during development (Korsching, 1993; Gao et al., 1995a) and are known to protect neurons from injury and toxins in adults (Hefti, 1986; Apfel et al., 1991; Hyman et al., 1991; Knusel et al., 1992; Yan et al., 1992; Koliatsos et al., 1993; Gao et al., 1995b). The best characterized mammalian neurotrophic factors are members of the nerve growth factor (NGF) family of proteins, and are called neurotrophins. These include NGF (Levi-Montalcini, 1987), brain-derived neurotrophic factor (BDNF).(Barde et al., 1982; Leibrock et al., 1989) neurotrophin-3 (NT-3) (Ernfors et al., 1990; Hohn et al., 1990; Jones and Reichardt, 1990; Maisonpierre et al., 1990; Rosenthal et al., 1990), and neurotrophin-4/5 (NT-4/5) (Berkemeier et al., 1991; Ip et al., 1992). Each of the neurotrophins binds to specific highaftinity receptors, the Trks (Klein et al., 1990; Kaplan et al., 1991; Klein et al., 1991a,b; Lamballe et al., 1991; Soppet et al., 1991; Squinto et al., 1991; Ip et al., 1993; Tsoulfas et al., 1993). For example, NGF selectively binds to TrkA, BDNF and NT4/5 to TrkB, and NT3 to TrkC. Although neurotrophins exert their main effects through binding to the Trks, they also bind to the NGF low-affinity receptor, P75 (Chao et al., 1986). Recent studies indicate that the binding of NGF to P75 may enhance the TrkA-mediated signal transduction pathway (Davies et al., 1993a; Barker and Shooter, 1994; Clary and Reichardt, 1994; Verdi et al., 1994).

In situ hybridization studies indicate that mRNAs for TrkB and TrkC are expressed by developing cochleovestibular ganglia (Ylikoski et al., 1993; Schecterson and Bothwell, 1994) and that mRNAs for BDNF and NT-3 are found in the inner ear including organ of Corti (Pirvola et al., 1992; Schecterson and Bothwell, 1994; Wheeler et al., 1994). However, the expression patterns of neurotrophin receptors have not been well determined at the protein level, and no study has compared the biological effects of the four neurotrophins on postnatal rodent SGNs. In particular, the survival-promoting effects of NT-4/5 have not been tested on SGNs. In the present experiments, we used TrkB and TrkA immunohistochemistry to provide direct experimental evidence that SGNs make TrkB protein, but not TrkA protein. Addition of NT-4/5 to the culture promoted postnatal rat SGN survival. The survival-promoting effect of NT-4/5 was dose dependent and was as potent as that of BDNF, but stronger than that of NT-3. In contrast, NGF did not show any detectable effects on the survival of cultured SGNs. Moreover, TrkB-IgG fusion 
protein, a specific antagonist for NT-4/5 and BDNF (Shelton et al., 1995), completely inhibited the survival-promoting effects of NT-4/5. These data, considered together, indicate that NT-4/5 is a potent and specific survival factor for SGNs. In addition, when cisplatin, a widely used chemotherapeutic agent with ototoxic side effects (Fleischman et al., 1975; Stadnicki et al., 1975; Nakai et al., 1982; Carenza et al., 1986), was added to the culture, SGN survival was reduced in a dose-dependent manner. NT-4/5 prevented or ameliorated the neurotoxic effects of cisplatin on SGNs in culture.

\section{Materials and Methods}

SGN cell culture. Cochleae were dissected from postnatal day 5 (P5) Wistar rats. After spiral ligament and stria vascularis tissues were removed, the remaining spiral ganglia were incubated in a mixture of $0.125 \%$ trypsin and $0.125 \%$ collagenase for $25 \mathrm{~min}$ at $37^{\circ} \mathrm{C}$. The enzyme was inactivated with a mixture of $0.005 \%$ soybean trypsin inhibitor (Sigma) and .005\% DNase (Worthington) before trituration with $0.05 \%$ DNase in BME. The dissociated cells were preplated on a 35 $\mathrm{mm}$ untreated tissue culture dish for $25 \mathrm{~min}$ to enrich the neuronal population. Under these experimental procedures, about $10 \%$ of the cell population were spiral ganglion neurons (SGNs), as determined by immunocytochemistry, with a monoclonal antibody (N52) against neurofilaments (200 kDa, Boehringer). The cell suspension was findly plated on polylysine $(500 \mu \mathrm{g} / \mathrm{ml}) / \mathrm{laminin}(10 \mu \mathrm{g} / \mathrm{ml})$-coated 16 -well LabTek slides in $200 \mu \mathrm{l}$ of serum-free medium (BME plus insulin-transferrinsodium selenite media supplement; Sigma 1-1884, 1\% BSA, 2 mM glutamine, $5 \mathrm{mg} / \mathrm{ml}$ glucose) without antibiotics (modified from Baired et al., 1992). Cells were plated at a density of $80,000 /$ well.

Cell counts and quantitation. After $2 \mathrm{~d}$ in culture, viable SGNs were identified by labeling with a neurofilament monoclonal antibody (N52, Boehringer), viewed under a Zeiss Axiophot microscope, and counted using a grid ocular reticule covering an area of $1 \mathrm{~mm}^{2}$. For each culture, about 10 randomly selected fields were counted. Data were collected from three to five cultures for each of the experimental groups. Data were then normalized as a percentage of the viable cells in the control cultures in each of the experiments. Two-tailed, unpaired $t$ test was used for statistical analysis.

Growth factors, TrkB-IgG, TrkC-IgG and cisplatin. All human recombinant neurotrophins (Genentech, Inc.) were added to the cultures at the time of plating. To block the effects of the neurotrophins, $1 \mu \mathrm{g} / \mathrm{ml}$ TrkB-IgG or TrkC-IgG (kindly provided by Dr. David Shelton), specific antagonists for NT-4/5 and BDNF or NT-3, respectively (Shelton et al., 1995), were added to some of the experimental cultures at the same time as the neurotrophins were added. In some experiments, cisplatin (Bristol-Myers Squibb), a chemotherapeutic agent that has ototoxic side effects (Fleischman et al., 1975; Stadnicki et al., 1975), was added at various concentrations at the time of plating, either alone or in combination with $10 \mathrm{ng} / \mathrm{ml}$ of different neurotrophins. In other experiments, epidermal growth factor (EGF) (Collaborative Research), basic fibroblast growth factor (bFGF) (Gibco), transforming growth factor- $\beta 1$ (TGF- $\beta 1$ ) (Genentech), TGF- $\beta 2$, TGF- $\beta 3$, and TGF- $\beta 5$ (R \& D Systems) were added to the culture at the time of plating.

Immunohistochemistry and Immunocytochemistry. For double-antibody labeling, cochlear tissue containing spiral ganglion were dissected from P5 rats and immersed immediately in $4 \%$ paraformaldehyde (in $0.1 \mathrm{M}$ phosphate buffer, $\mathrm{pH} 7.4$ ) for $1 \mathrm{hr}$. After the preparations were cryoprotected with a $30 \%$ sucrose solution, cross-sections were cut on a cryostat. The sections were first blocked with a $10 \%$ normal goat serum in $1 \%$ Triton X-100 in phosphate-buffered saline (PBS) for 20 min and then incubated with a mixture of a monoclonal antibody (N52) against neurofilament $200 \mathrm{kDa}$ (Boehringer, $5 \mu \mathrm{g} / \mathrm{ml}$ ) and a rabbit antibody against the extracellular domain of TrkB (anti-TrkB ${ }_{23-36}, 2 \mu \mathrm{g} / \mathrm{ml}$; Yan et al., 1994; Gao et al., 1995a), a TrkA antiserum (1:10,000, Clary et al., 1994), or an antiserum against P75 (1:10,000, Weskamp and Reichardt, 1991) in PBS containing 3\% nornal goal serun and $1 \%$ Triton X-100 overnight at $4^{\circ} \mathrm{C}$. FITC-conjugated goat anti-mouse and Texas red-conjugated goat anti-rabbit secondary antibodies (1:70-100; Cappel) were then used to reveal the double labeling pattern in the sections of spiral ganglion. For neurofilament immunohistochemistry on cochlear whole mounts, the preparations were incubated with primary antibody for $2 \mathrm{~d}$ at $4^{\circ} \mathrm{C}$ and then Texas red-conjugated goat anti-mouse antiserum (1:100, Cappel) was used to reveal the staining patterns.
For neurofilament immunocytochemistry, SGN cultures were fixed in $4 \%$ paraformaldehyde (in $0.1 \mathrm{M}$ phosphate buffer, $\mathrm{pH} 7.4$ ) for $30 \mathrm{~min}$, washed in PBS (pH 7.4), and the immunostainings were performed with a biotinylated sheep anti-mouse secondary antibody and a streptavidinhorse radish peroxidase conjugate (1:200, Amersham Life Science), as described (Gao et al., 1995b).

\section{Results}

$N T-4 / 5$ is a potent and specific survival factor for SGNs in culture

When cochlear tissue containing both the spiral ganglion and organ of Corti was immunolabeled with a monoclonal antibody (N52) against neurofilament protein $(200 \mathrm{kDa})$, the somata and processes of the SGNs were intensively stained (Fig. 1A). Neuronal innervations of hair cells in the organ of Corti from the cell somata in the spiral ganglion were casily scen (Fig. 1A). This antibody was, therefore, used to identify SGNs in the dissociated cell cultures.

SGNs were dissociated from postnatal day 5 (P5) rat cochleae and plated in defined serum-free medium. In control cultures (Fig. $1 B$ ), about $75 \%$ of SGNs died after $2 \mathrm{~d}$, presumably due to a lack of growth factors. Addition of NT-4/5 to the culture greally enhanced the number of surviving SGNs (Fig. 1C), in a dose-dependent manner (Fig. 2). A wide range of doses (from $0.1 \mathrm{ng} / \mathrm{ml}$ to $50 \mathrm{ng} / \mathrm{ml}$ ) were tested and a maximal effect of approximately threefold increase was seen at a concentration of $10 \mathrm{ng} / \mathrm{ml}$. Neurofilament immunocytochemical staining revealed that cultured SGNs showed bipolar or Y-shaped branching patterns, as seen in vivo.

We also examined possible effects of other neurotrophins including NGF, BDNF, and NT-3 on SGN survival in vitro. Among the four neurotrophins, BDNF was equal in potency to NT-4/5 at concentrations from $1-50 \mathrm{ng} / \mathrm{ml}(p<0.001$ as compared to the control; Fig. 3). At $0.1 \mathrm{ng} / \mathrm{ml}$, NT-4/5 was more potent than BDNF $(p<0.01)$. NT-3 also displayed a significant survival-promoting effect $(p<0.05$ at $0.1 \mathrm{ng} / \mathrm{ml} ; p<0.001$ at higher doses), although this effect was less potent than NT-4/5 or BDNF at all doses $(0.1-50 \mathrm{ng} / \mathrm{ml})(p<0.001)$. In contrast, NGF showed no detectable effects in SGN cultures at all doses we examined (Fig. 3).

To test whether NT-4/5, BDNF and NT-3 have synergistic effects, we added NT-4/5 together with BDNF or NT-3 into the culture; no additive effects were observed at saturated concentrations (Fig. 3).

To determine if SGNs respond to other growth factors, we added epidermal growth factor (EGF), basic fibroblast growth factor (bFGF), transforming growth factor- $\beta 1$ (TGF- $\beta 1$ ), TGF$\beta 2$, TGF- $\beta 3$, or TGF- $\beta 5$ to the cultures. No survival-promoting effects were seen, suggesting selective responses of SGNs to NT-4/5, BDNF and NT3.

\section{SGNs make TrkB protein, the high-affinity binding receptor for $B D N F$ and $N T-4 / 5$}

To determine whether SGNs make trkB protein, the high-affinity binding receptor for BDNF and NT-4/5, TrkB immunohistochemistry was performed on cross-sections of P5 spiral ganglion with a polyclonal antiserum against TrkB extracellular domain (TrkB ${ }_{23-36}$; Yan et al., 1994; Gao et al., 1995a). As shown in Figure $4 A$, both the somata and processes of SGNs in the spiral ganglion were labeled. In contrast, TrkA antiserum (Clary et al., 1994) failed to detect the presence of TrkA protein in these neurons (Fig. 4C). These results suggest that the effects of NT4/5 and BDNF on these neurons are direct. 

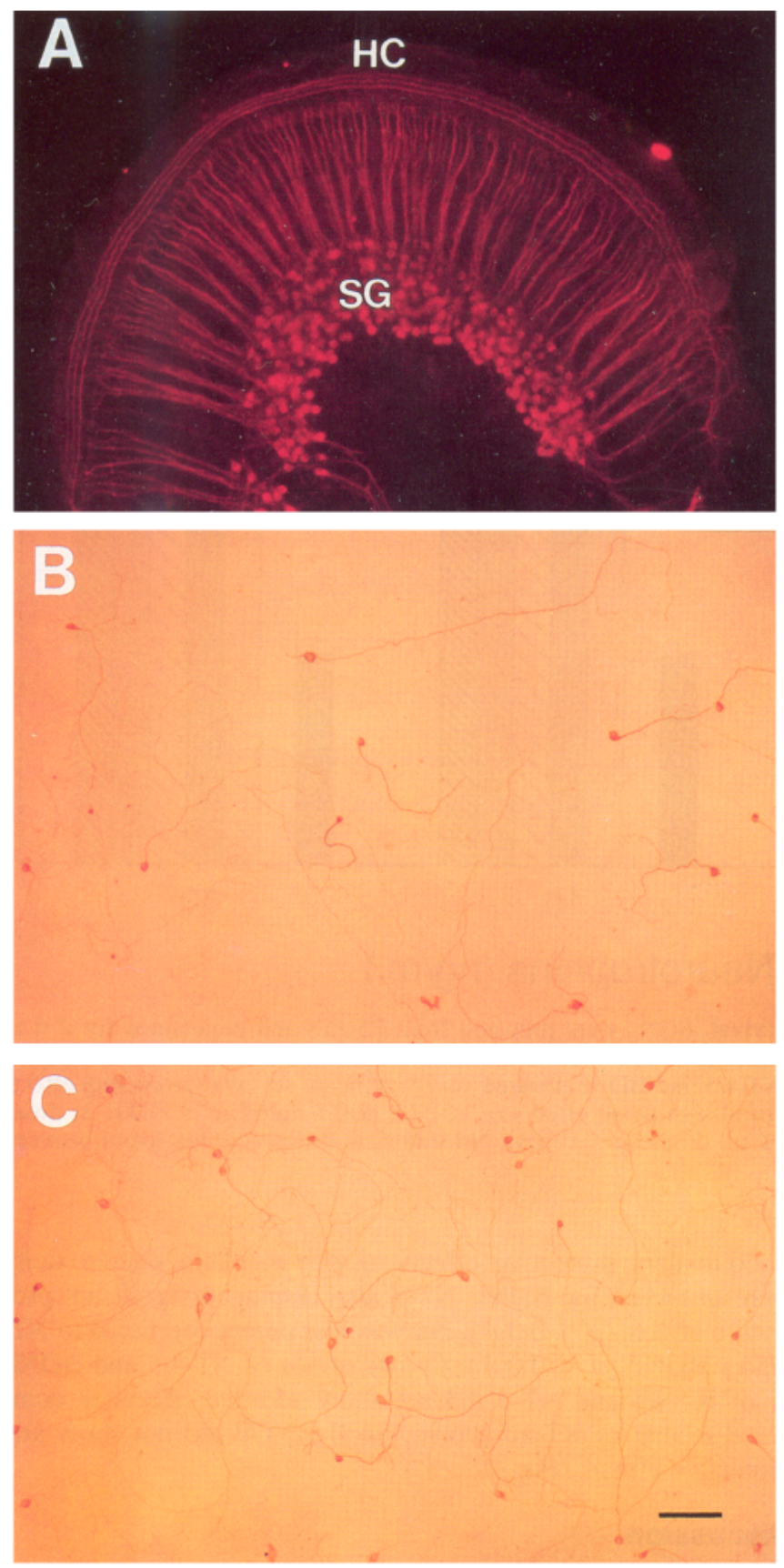

Figure 1. NT-4/5 promotes the survival of cultured SGNs. A, Texas red microscopy shows neurofilament immunohistochemistry on wholemount of P5 cochlear tissue. Both the somata and processes of SGNs were heavily labeled and their innervation of hair cells was evident. $B$ and $C$, Bright-field microscopy demonstrates neurofilament protein immunocytochemistry in the SGN cultures in serum-free medium alone $(B)$ or in medium containing $10 \mathrm{ng} / \mathrm{ml}$ of NT-4/5 $(C)$, respectively. Identical results (not shown) were also obtained with a different neuronal marker, a monoclonal antibody 3A10 (Furley et al., 1990). Note that NT-4/5 greatly enhanced the survival of cultured SGNs. Abbreviations: $S G$, spiral ganglion; $H C$, hair cells. Scale bar, $100 \mu \mathrm{m}$.

When the sections of spiral ganglion were double labeled with a monoclonal antibody (N52) against neurofilament protein and TrkB or TrkA antiserum, the majority of the neurofilament-positive SGNs were also labeled by the TrkB antiserum (Fig. 4A,B), but not the TrkA antiserum (Fig. $4 C, D$ ), suggesting that most

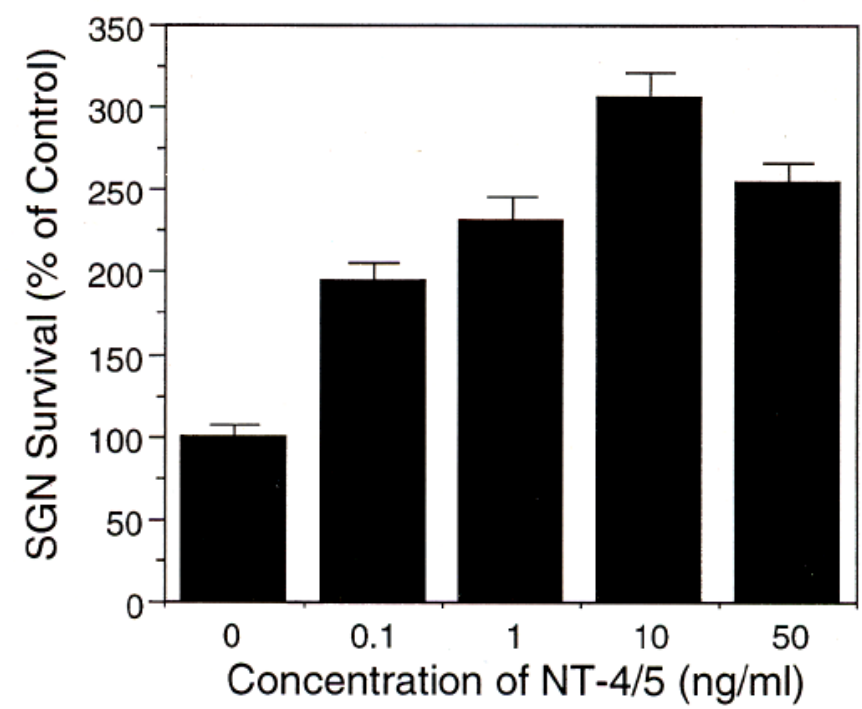

Figure 2. Quantitation of the effects of NT-4/5 on SGN survival. SGNs were prepared from P5 rats, plated and kept for $2 \mathrm{~d}$ in serumfree medium in the absence or presence of NT- $4 / 5$ at different concentrations. Viable SGNs were identificd by labeling with a neurofilament monoclonal antibody (N52), viewed under a Zeiss Axiophot microscope, and counted using a grid ocular reticule covering an area of 1 $\mathrm{mm}^{2}$. For each culture, about 10 randomly selected fields were counted. Data were collected from three to five cultures and normalized as a percentage of the number of viable neurons in the control cultures in each of the experiments. The error bars represent SEM. As compared to control cultures, NT-4/5 showed very significant survival-promoting effects on SGNs at all doses ( $p<0.001$, two-tailed, unpaired $t$ test).

SGNs produce TrkB, but not TrkA proteins. It is of interest that SGNs were also immunoreactive to an antiserum against P75 (Weskamp and Reichardt, 1991, the low-affinity receptor for all neurotrophins. It appeared that all SGNs made the P75 protein (Fig. $4 E, F$ ). In addition, both TrkB and P75 immunostainings extended into the cochlear epithelium; however, the immunoreactivities were confined to the afferent nerve terminals of SGNs, but were undetectable in the hair cells.

\section{TrkB-IgG fusion protein blocks the survival-promoting activity of NT-4/5}

To provide further evidence that NT-4/5 acts specifically on the SGNs, we added TrkB-IgG fusion protein, a specific antagonist for NT-4/5 and BDNF (Shelton et al., 1995), to the SGN cultures containing NT-4/5 or BDNF. As shown in Figure 5, addition of the TrkB-IgG fusion protein completely inhibited the survivalpromoting effects of NT-4/5 and/or BDNF. As expected, the TrkB-IgG fusion protein did not block the activity of NT-3. On the other hand, TrkC-IgG fusion protein, a specific antagonist for NT-3 (Shelton et al., 1995), abolished the effects of NT-3, but failed to block the effects of NT-4/5 and/or BDNF (Fig. 5). The specific blocking effects of TrkB-IgG or TrkC-IgG on NT$4 / 5$ and BDNF or NT3, respectively, were also seen when more than one neurotrophin was present in the culture. In addition, TrkB-IgG and/or TrkC-IgG themselves did not show detectable effects on the survival of SGNs in normal cultures (Fig. 5). These experiments, considered together, confirmed the specificity of TrkB-IgG and TrkC-IgG and support the notion that the survival-promoting effects of NT-4/5 on SGNs are specific. 


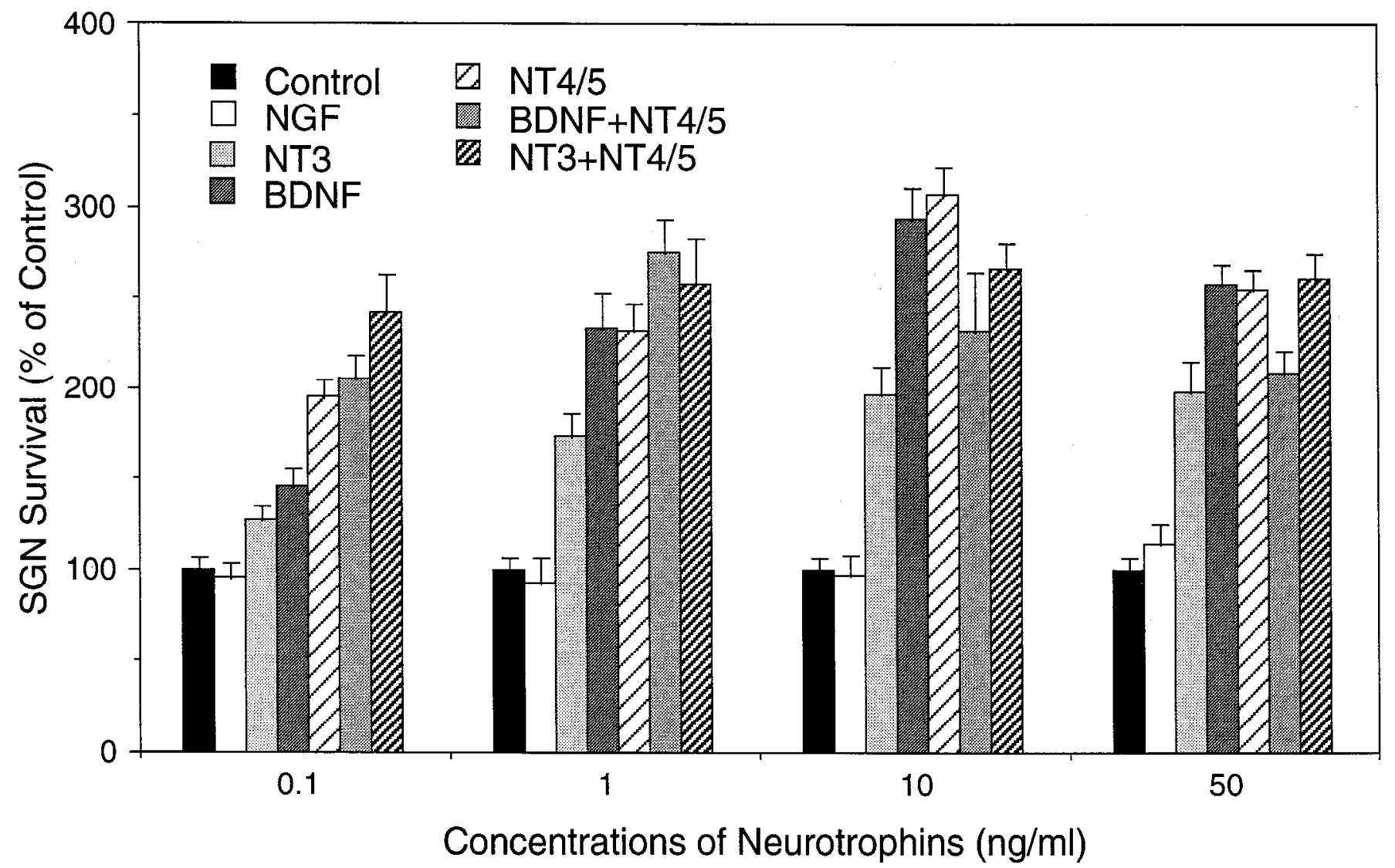

Figure 3. Quantitation of the effects of different neurotrophins on SGN survival. SGNs were prepared from P5 rats and maintained for $2 \mathrm{~d}$ in serum-free medium without or with different neurotrophins at different concentrations. Quantitation of viable SGNs was made in the same way as in Figure 2 and the error bars are SEM. When compared to control cultures, NT-4/5 and BDNF showed very significant survival-promoting effects on SGNs at all doses $(p<0.001$, two-tailed, unpaired $t$ test). NT-3 also showed significant effects $(p<0.05$ at $0.1 \mathrm{ng} / \mathrm{ml} ; p<0.001$ at doses from $1-50 \mathrm{ng} / \mathrm{ml})$. Difference between NT3 and NT-4/5 was very significant at all doses $(p<0.001)$. No statistical difference was found between NT- $4 / 5$ and BDNF except the dose of $0.1 \mathrm{ng} / \mathrm{ml}(p<0.01)$.

\section{$N T-4 / 5, B D N F$, and $N T-3$, but not $N G F$, protect SGNs against cisplatin neurotoxicity}

Cisplatin, a widely used chemotherapeutic agent, produces ototoxic side effects (Fleischman et al., 1975; Stadnicki et al., 1975; Nakai et al., 1982; Carenza et al., 1986). When cisplatin was added to the SGN cultures, it induced a dose-dependent inhibition of SGN survival (Fig. 6). At a dose of $4 \mu \mathrm{g} / \mathrm{ml}$ or higher, virtually all SGNs died in the culture within $2 \mathrm{~d}$. In contrast, cisplatin, at a concentration of $4 \mu \mathrm{g} / \mathrm{ml}$, had no inhibitory effects on survival of postnatal neurons harvested from the CNS such as cerebellar granule neurons or hippocampal neurons in vitro; the majority of cerebellar granule neurons and hippocampal neurons survived and elaborated neurites in the culture containing 4-6 $\mu \mathrm{g} / \mathrm{ml}$ of cisplatin (J. L. Zheng and W.-Q. Gao, unpublished observations), suggesting that SGNs are selectively vulnerable to cisplatin.

To determine if NT-4/5 could protect the SGNs from cisplatin neurotoxicity, NT-4/5 was added along with three different doses of cisplatin. At concentrations of $1 \mu \mathrm{g} / \mathrm{ml}$ or $2 \mu \mathrm{g} / \mathrm{ml}$ cisplatin, the percentage of surviving SGNs was higher than that in the control cultures lacking cisplatin (Fig. 7). This suggests that NT$4 / 5$ promotes SGN survival and protects SGNs from cisplatin neurotoxicity. At $4 \mu \mathrm{g} / \mathrm{ml}$ of cisplatin, NT-4/5 still significantly protected SGNs from cell death $(p<0.001)$, although the survival level was only $70 \%$ of control cultures in the absence of cisplatin (Fig. 7).
Equivalent protective effects against cisplatin neurotoxicity were observed for BDNF. NT-3 also displayed significant protective effects $(p<0.001)$, but was less potent compared to NT$4 / 5$ or BDNF $(p<0.001)$. Combinations of NT-4/5 and BDNF or of NT-4/5 and NT-3 did not show additive effects as compared to that of NT-4/5 alone. Finally, NGF did not show any protective effects (Fig. 7).

\section{Discussion}

In the present study, we have demonstrated that NT-4/5 promotes the survival of cultured P5 rat SGNs and protects them against neurotoxicity by cisplatin. Of the four known neurotrophins, NT-4/5 and BDNF are equivalently potent survival factors and more potent than NT-3. In contrast, NGF has no effect on SGN survival.

The differential survival-promoting effects of NT-4/5 or BDNF and NGF on cultured SGNs are consistent with the expression pattern of $\operatorname{TrkB}$ and $\operatorname{TrkA}$ receptors in these neurons. The negative staining of TrkA antiserum correlates well with the negative results of NGF on these neurons. The detection of TrkB protein in the SGNs in the present experiment provides strong support for direct actions of NT-4/5 and BDNF on the SGNs. Our immunohistochemistry is also in agreement with an earlier study by Vazquez and his co-workers (Vazquez et al., 1994), which shows TrkB immunoreactivity in the embryonic mouse cochleovestibular ganglion. It is of interest that SGNs also pro- 

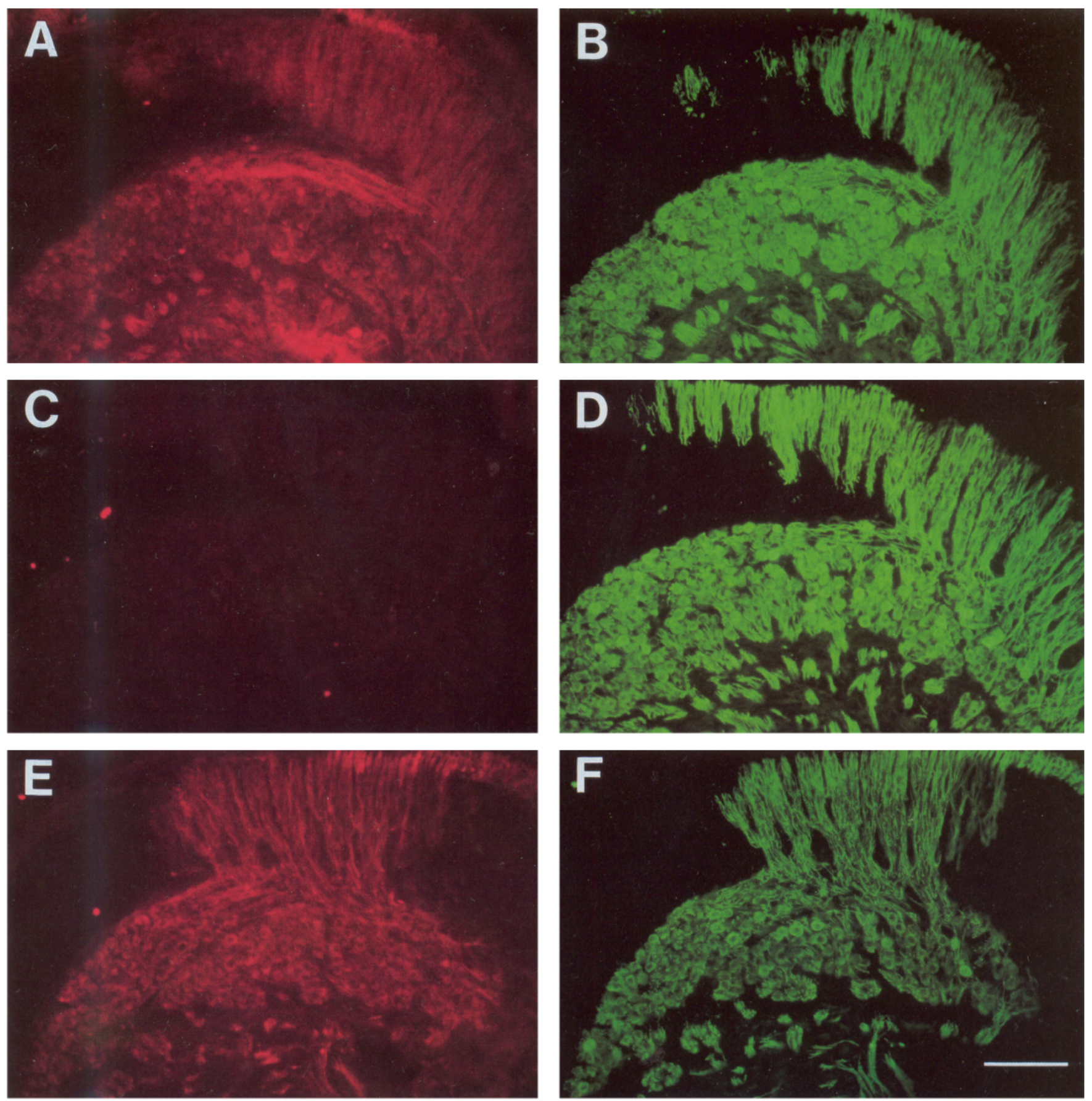

Figure 4. Dual-immunohistochemistry on cross sections of the spiral ganglion with TrkB, TrkA, or P75 and neurofilament protein antibodies. A, $C$, and $E$, Texas red microscopy shows the staining pattern of antibodies against TrkB, TrkA, and P75, respectively. $B, D$, and $F$, Fluorescence microscopy shows the immunostainings of neurofilament antibody (N52) in the same sections as shown in $A, C$, and $E$. N52 labeled intensely somata and processes of SGNs. Note that while SGN somata and processes were heavily labeled by TrkB and P75 antibodies ( $A$ and $E$ ), no staining by TrkA antiserum was evident $(C)$. Scale bar, $100 \mu \mathrm{m}$.

duce P75 protein, a low-affinity binding protein for all four neurotrophins. The expression of P75 in SGNs has also been described by others (von Bartheld et al., 1991; Ylikoski et al., 1993; Schecterson and Bothwell, 1994). Although the biological function of P75 remains unclear, recent studies indicate that the binding between NGF and P75 may enhance the TrkA-mediated signal transduction pathway (Davies et al., 1993b; Barker and Shooter, 1994; Clary and Reichardt, 1994; Verdi et al., 1994). Since an immunohistochemically specific antibody against TrkC receptor is lacking, we have not determined the expression pattern of TrkC protein in these cells. As mRNAs for both TrkB and TrkC have been found in the developing cochleovestibular ganglion (Ylikoski et al., 1993; Schecterson and Bothwell, 1994), it is possible that the SGNs coexpress both TrkB and TrkC genes. The decreased potency of NT-3 compared to NT$4 / 5$ or BDNF and the absence of additive effects when NT-3 is combined with NT-4/5 suggest that TrkC signaling is not coupled as effectively as TrkB signaling to support survival (Tsoul- 
Figure 5. TrkB-IgG protein inhibits the survival-promoting activity of NT$4 / 5$ or BDNF. SGNs were prepared from $P 5$ rats and kept for $2 \mathrm{~d}$ in serumfree medium containing $1 \mu \mathrm{g} / \mathrm{ml}$ TrkBIgG and/or TrkC-IgG alone or in combination with $10 \mathrm{ng} / \mathrm{ml}$ neurotrophins. Quantitation of viable SGNs was done in the same way as in Figure 2. The error bars indicate SEM.

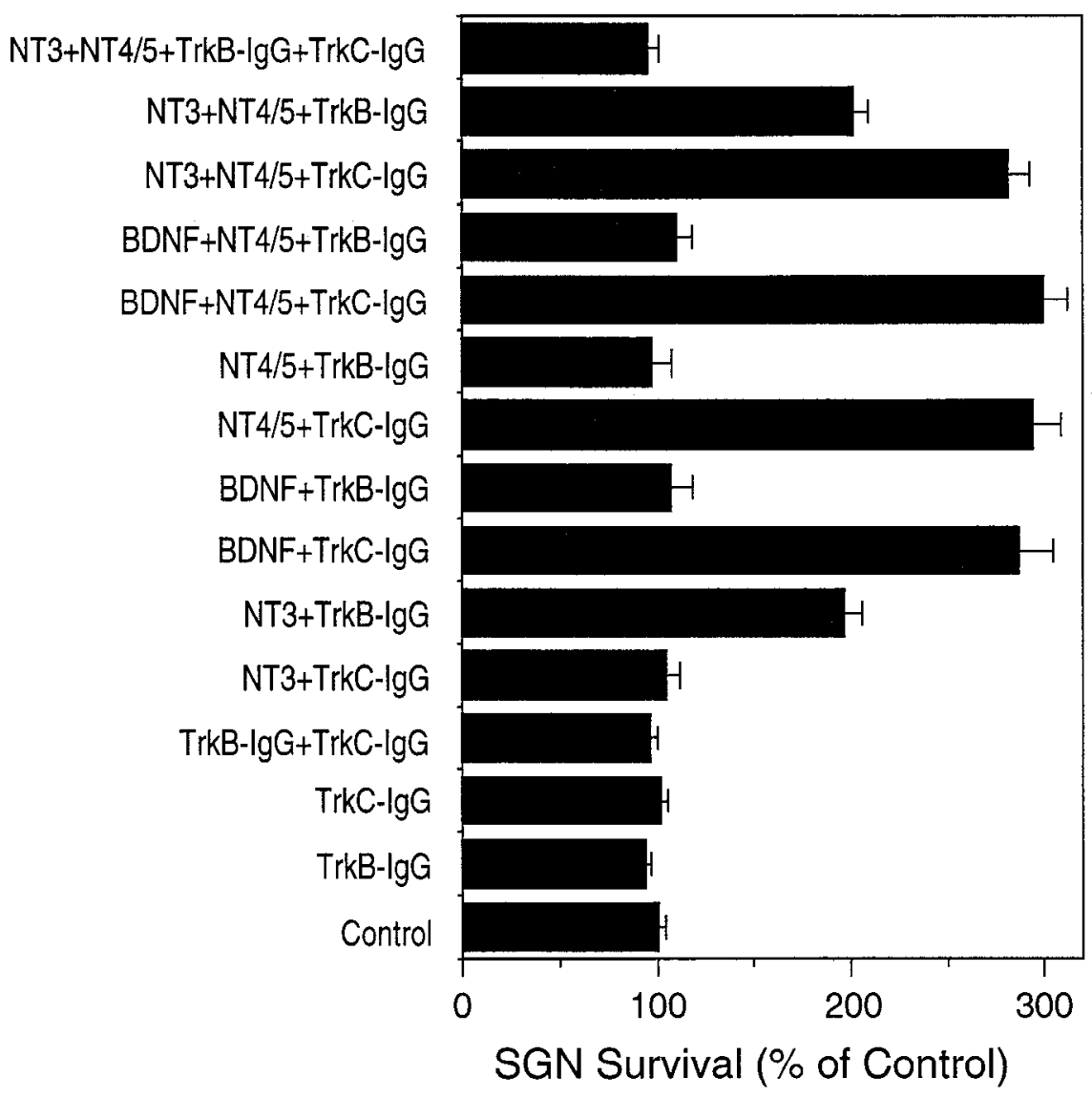

fas et al., 1993; Valenzuela et al., 1993; Garner and Large, 1994).

Although both NT-4/5 and BDNF could activate the same TrkB receptor (Berkemeier et al., 1991; Ip et al., 1992; Ip et al., 1993; Escandon et al., 1994), their actions are not completely identical. Subtle differences in their effectiveness have been ob-

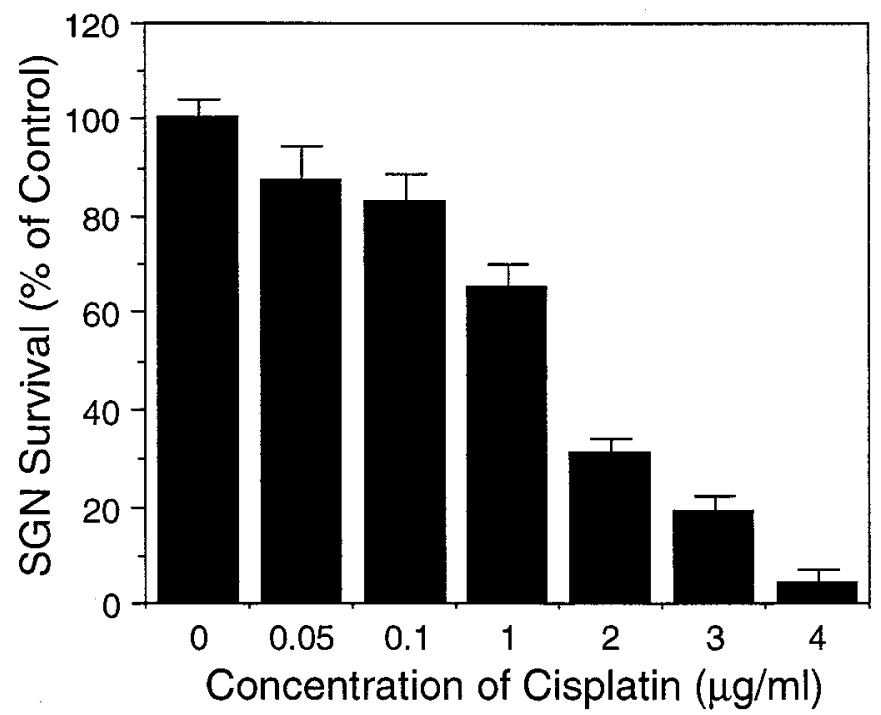

Figure 6. Cisplatin induces a dose-dependent neuronal cell death. SGNs were prepared from P5 rats, plated in serum-free medium containing different doses of cisplatin, and assayed after $2 \mathrm{~d}$ in culture. Quantitation of viable SGNs was made in the same way as in Figure 2. The error bars are SEM. served in NIH-3T3 cells transfected with TrkB receptors (Ip et al., 1993), in cultured embryonic cerebellar Purkinje cells (Lärkfors et al., 1993), and in aged animals with learning and memory deficits (Fischer et al., 1994). Because of these differences in effectiveness, it seems important to compare the actions of NT$4 / 5$ and BDNF on SGN survival. In the present study, although NT-4/5 is more potent than BDNF at a concentration of 0.1 $\mathrm{ng} / \mathrm{ml}$, they show equivalent effectiveness at concentrations from $1-50 \mathrm{ng} / \mathrm{ml}$. Similar results have been observed on cultured postnatal cerebellar granule neurons (Gao et al., 1995a). The equal potency of NT-4/5 and BDNF on neuronal survival has also been seen in cultures of embryonic midbrain dopaminergic neurons (Hynes et al., 1994), embryonic sensory neurons (Davies et al., 1993b), and adult retinal ganglion neurons (Cohen et al., 1994). In addition, it is important to note that no additive effects are observed when both NT-4/5 and BDNF are present in the culture at saturated concentrations tested. TrkB-IgG, but not TrkC-IgG, completely blocks the survival-promoting activity of NT-4/5 and/or BDNF. Furthermore, EGF, bFGF, TGF- $\beta 1$, TGF- $\beta 2$, TGF$\beta 3$, or TGF- $\beta 5$ does not show any effects in the SGN cultures. These results support the notion that NT-4/5 and BDNF act specifically on the SGNs and both NT-4/5 and BDNF activate the same receptor, TrkB, for signal transduction. During preparation of the manuscript, Lefebvre et al. (1994) reported that BDNF and NT-3 support the survival of adult SGNs. The present study is in agreement with the earlier report with BDNF and NT-3. In addition, our experiments demonstrate specific and potent survival-promoting effects of NT-4/5 and provide the first evidence that NT-4/5 and BDNF have similar survival-promoting effects on SGNs. 


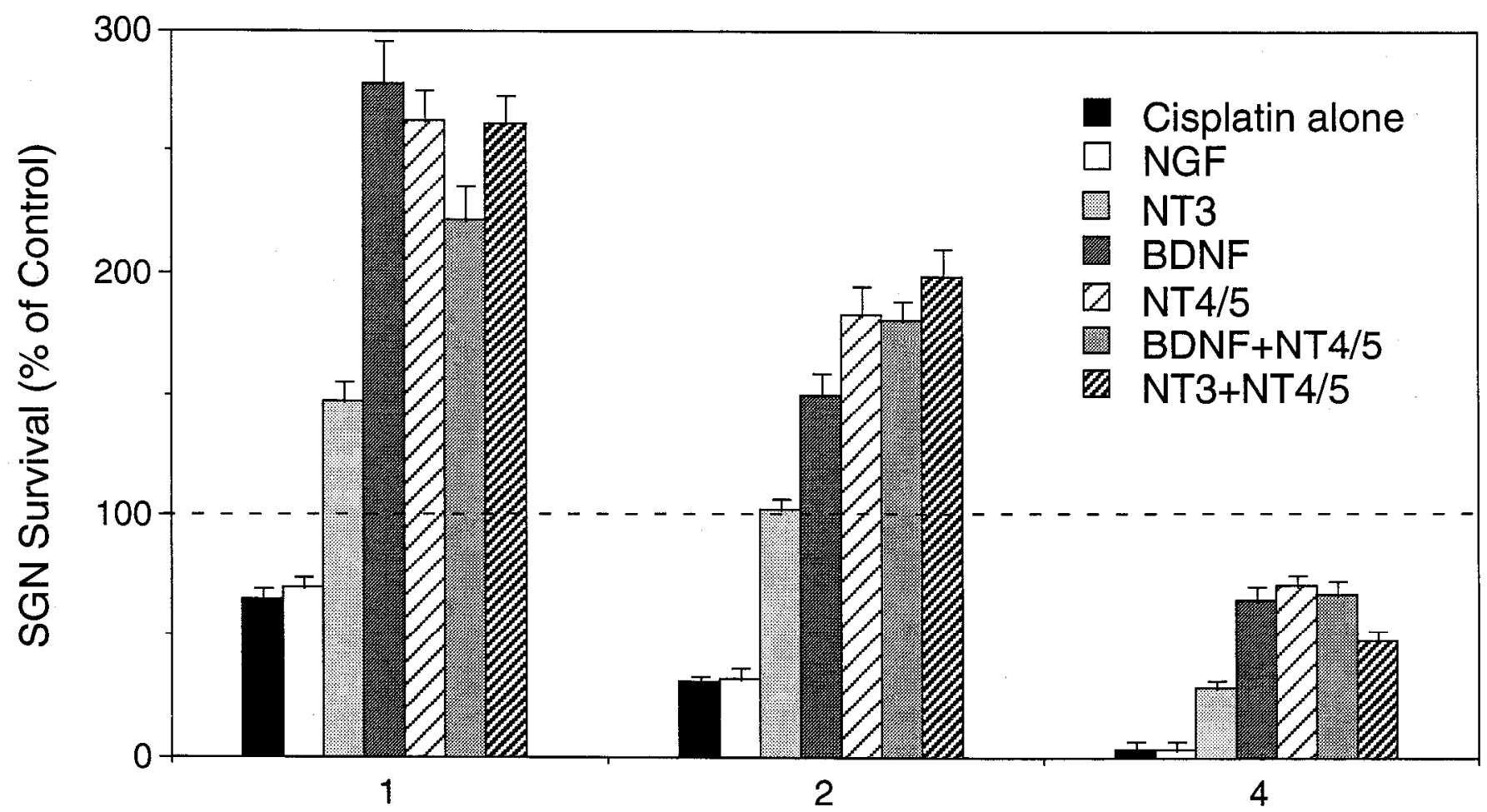

\section{Concentration of Cisplatin $(\mu \mathrm{g} / \mathrm{ml})$}

Figure 7. NT-4/5, BDNF and NT-3 protect SGNs against cisplatin neurotoxicity. SGNs were prepared from P5 rats and cultured for $2 \mathrm{~d}$ in serumfree medium containing $1 \mu \mathrm{g} / \mathrm{ml}, 2 \mu \mathrm{g} / \mathrm{ml}$, or $4 \mu \mathrm{g} / \mathrm{ml}$ of cisplatin alone or with $10 \mathrm{ng} / \mathrm{ml}$ of different neurotrophins. Quantitation of viable SGNs was done in the same way as in Figure 2. The error bars stand for SEM. The dashed horizontal line indicates the survival level of normal cultures without cisplatin. Note that even in the cultures containing $4 \mu \mathrm{g} / \mathrm{ml}$ cisplatin. NT-4/5, RDNF and NT3 showed very significant protecting effects on SGNs as compared to the culture containing cisplatin alone $(p<0.001)$. Although no difference was found between cultures containing NT$4 / 5$ and cultures containing BDNF, the difference between cultures containing NT-3 and cultures containing NT-4/5 or BDNF was statistically very significant $(p<0.001)$.

Previous in situ hybridization studies have indicated that mRNA for neurotrophins including BDNF and NT-3 are found in the inner ear including cochlear tissues (Pirvola et al., 1992; Schecterson and Bothwell, 1994; Wheeler et al., 1994). At present, it is not known if hair cells in the organ of Corti, the peripheral target tissue for SGNs, make NT-4/5. We have attempted and failed to detect neurotrophins in the extract of organ of Corti with ELISA that can measure neurotrophins at a range of $10^{-9} \mathrm{~g} / \mathrm{ml}$ (40 Corti's organs $/ \mathrm{ml}$ ), suggesting the levels of neurotrophins are very low. However, it is quite possible that the organ of Corti produces more than one trophic factor for survival of SGNs. Support for this notion comes from recent gene deletion experiments in which the genes coding for neurotrophins are deleted (see a recent review by Snider, 1994). For example, in the NT-3 knock-out mice, there is a great loss of SGNs (Fariñas et al., 1994). However, in the mice lacking BDNF, neuronal innervation of cochlear hair cells is unaffected and the mice have normal auditory responses (Ernfors et al., 1994), presumably reflecting compensation between BDNF and NT-4/5 or NT-3.

On the other hand, it should be noted that in contrast to other sensory neurons that are completely dependent upon neurotrophins for survival (Davies et al., 1986), approximately 20-25\% of cultured SGNs survive even in the absence of neurotrophins in the present experiments. This population survives for a longer time (4-6 d) in cultures without neurotrophins (data not shown). Although this could be due to endogenous neurotrophins coming from SGNs or non-neuronal cells in the culture, the result that addition of TrkB-IgG and TrkC-IgG to the control culture without exogenous neurotrophins does not significantly affect the survival percentage of the SGNs, makes this possibility unlikely. Therefore, a small subpopulation of SGNs may be neurotrophinindependent at and after birth. Supportive evidence comes from a study by Guild and his co-workers (Guild et al., 1931), which showed that when the organ of Corti, the peripheral target for SGNs, and the peripheral axons of the SGNs are completely atrophied, approximately $25 \%$ of the SGNs remain intact.

Cisplatin, a widely used chemotherapeutic agent for several types of cancer, has two unfortunate side effects in the nervous system: peripheral sensory neuropathy (Roelofs et al., 1984; Thompson et al., 1984; Mollman, 1990; Siegal and Haim, 1990) and ototoxicity (Fleischman et al., 1975; Stadnicki et al., 1975; Nakai et al., 1982; Carenza et al., 1986). When neuronal cultures were prepared from different CNSs and PNSs, cisplatin selectively damaged large sensory neurons in the dorsal root ganglia and neurons in cochleovestibular ganglion (Zheng and Gao, unpublished observations). In the case of cisplatin-induced peripheral sensory neuropathy in which TrkC-expressing DRG neurons are affected, NT-3 protects and reverses the pathological changes induced by cisplatin in both sensory nerve conduction velocity and abnormal cytoplasmic patching of neurofilament protein (Gao et al., 1995b). Our findings that N'I-4/5 effectively promotes survival of cultured SGNs and protects SGNs from cisplatin ncurotoxicity suggest that this factor may be uscful in prevention of injury or toxin-induced hearing impairment. 


\section{References}

Apfel SC, Lipton RB, Arezzo JC, Kessler JA (1991) Nerve growth factor prevents toxic ncuropathy in micc. Ann Ncurol 29:87-89.

Baired DH, Hatten ME, Mason CA (1992) Cerebellar target neurons provide a stop signal for afferent neurite extension in vitro. J Neurosci 12:619-634.

Barde YA, Edgar D, Thoenen H (1982) Purification of a new neurotrophic factor from mammalian brain. EMBO J 1:549-553.

Barker PA, Shooter EM (1994) Disruption of NGF binding to the low affinity neurotrophin receptor $\mathrm{p} 75^{\mathrm{LNTR}}$ reduces NGF binding to TrkA on PC12 cells. Neuron 13:203-215.

Berkemeier LR, Winslow JW, Kaplan DR, Nikolics K, Goeddel DV, Rosenthal A (1991) Neurotrophin-5: a novel neurotrophic factor that activates trk and trkB. Neuron 7:857-866.

Carenza L, Villani C, Framarino dei Malatesta ML, Prosperi Porta R, Millefiorine M, Antonini G, Bolasco P, Bandiera G, Marzetti L (1986) Peripheral neuropathy and ototoxicity of dichlorodiamineplatinum: instrumental evaluation. Gynecol Oncol 25:244-249.

Chao MV, Bothwell MA, Ross AH, Koprowski H, Lanahan AA, Buck CR, Sehgal A (1986) Gene transfer and molecular cloning of the human NGF receptor. Science 232:518-521.

Clary DO, Reichardt LF (1994) An alternatively spliced form of the nerve growth factor receptor TrkA confers an enhanced response to neurotrophin 3. Proc Natl Acad Sci USA 91:11133-11137.

Clary DO, Weskamp G, Austin LR, Reichardt LF (1994) TrkA crosslinking mimics neuronal responses to nerve growth factor. Mol Biol Cell 5:549-563

Cohen A, Bray GM, Aguayo AJ (1994) Neurotrophin-4/5 (NT-4/5) increases adult rat retinal ganglion cell survival and neurite outgrowth in vitro. J Neurobiol 25:953-959.

Davies AM, Thoenen H, Barde Y-A (1986) Different factors from the central nervous system and peripheral regulate the survival of sensory neurons. Nature 319:497-502.

Davies AM, Lee KF, Jaenisch R (1993a) p75-deficient trigeminal sensory neurons have an altered response to NGF but not to other neurotrophins. Neuron 11:565-574.

Davies AM, Horton A, Burton LE, Schmelzer C, Vandlen R, Rosenthal A (1993b) Neurotrophin-4/5 is a mammalian-specific survival factor for distinct populations of sensory ncurons. J Ncurosci 13:49614967.

Dublin WB (1976) Fundamentals of sensorineural auditory pathology. Springfield, IL: Thomas.

Ernfors P, Ibanez CF, Ebendal T, Olson L, Persson H (1990) Molecular cloning and neurotrophic activities of a protein with structural similarities to nerve growth factor: developmental and topographic expression in the brain. Proc Natl Acad Sci USA 87:5454-5458.

Ernfors P, Lee K-F, Jaenisch R (1994) Mice lacking brain-derived neurotrophic factor develop with sensory deficits. Nature 368:147-150.

Escandon E, Soppet D, Rosenthal A, Mendoza-Ramierz J-L, Szonyi E, Burton LE, Henderson CE, Parada LF, Nikolics K (1994) Regulation of neurotrophin receptor expression during embryonic and postnatal development. J Neurosci 14:2054-2068.

Fariñas I, Jones KR, Backus C, Wang X-Y, Reichardı LF (1994) Severe sensory and sympathetic deficits in mice lacking neurotrophins-3. Nature 369:658-661.

Fischer W, Sirevaag A, Wiegand SJ, Lindsay RM, Björklund A (1994) Reversal of spatial memory impairments in aged rats by nerve growth factor and neurotrophins 3 and $4 / 5$ but not by brain-derived neurotrophic factor. Proc Natl Acad Sci USA 91:8607-8611.

Fleischman RW, Stadnicki SW, Ethier MF, Schaeppi U (1975) Ototoxicity of cis-dichlorodiammine platinum (II) in the guinea pig. Toxicol Appl Pharmacol 33:320-332.

Furley A, Morton SB, Malano D, Karagogeos, Dodd J, Jessell TM (1990) The axonal glycoprotein TAG-1 is an immunoglobin superfamily member with neurite outgrowth-promoting activity. Cell 61: $157-170$.

Gao W-Q, Zheng JL, Karihaloo M (1995a) Neurotrophin-4/5 (NT-4/5) and brain-derived neurotrophic factor (BDNF) act at later stages of cerebellar granule cell differentiation. J Neurosci 15:2656-2667.

Gao W-Q, Dybdal N, Shinsky N, Murnane A, Schmelzer C, Siegel M, Keller G, Hefti F, Phillips HS, Winslow JW (1995b) Neurotrophin-3 reverses experimental cisplatin-induced peripheral sensory neuropathy. Ann Neurol, in press.

Garner AS, Large TH (1994) Isoforms of the avian TrkC receptor: a novel kinase insertion dissociates transformation and process outgrowth from survival. Neuron 13:457-472.

Guild S, Cowe S, Bunch C, Polvogt (1931) Correlations of differences in sensory of innervation of the organ of Corti with differences in the acuity of hearing, including evidences as to the location in the human cochlea of receptors for certain tones. Acta Otolaryngol (Stockh) 15:269-308.

Hefti F (1986) Nerve growth factor (NGF) promotes survival of septal cholinergic neurons after fimbrial transections. J Neurosci 6:21552162 .

Hohn A, Leibrock J, Bailey K, Barde YA (1990) Identification and characterization of a novel member of the nerve growth factor/brainderived neurotrophic factor family. Nature 344:339-341.

Hood JL, Berlin CI, eds. (1986) Contemporary applications of neurobiology in human hearing assessment. New York: Raven.

Hyman C, Hofer M, Barde YA, Juhasz M, Yancopoulos GD, Squinto SP, Lindsay RM (1991) BDNF is a neurotrophic factor for dopaminergic neurons of the substantia nigra. Nature 350:230-233.

Hynes MA, Poulsen K, Armanini M, Berkemeier L, Phillips H, Rosenthal A (1994) Neurotrophin-4/5 is a survival factor for embryonic midbrain dopaminergic neurons in enriched cultures. J Neurosci Res 37:144-154.

Ip NY, Ibáñez CF, Nye SH, McClain J, Jones PF, Gies DR, Belluscio L, LeBeau MM, Espinso III R, Squinto SP, Persson H, Yancopoulos GD (1992) Mammalian neurotrophin-4: structure, chromosomal localization, tissue distribution, and receptor specificity. Proc Natl $\Lambda$ cad Sci USA 89:3060-3064.

Ip NY, Stitt TN, Tapley P, Klein R, Glass DJ, Fandl J, Greene LA, Barbacid M, Yancopoulos GD (1993) Similarities and differences in the way neurotrophins interact with the Trk receptors in neuronal and nonneuronal cells. Neuron 110:137-149.

Jones KR, Reichardt LF (1990) Molecular cloning of a human gene that is a member of the nerve growth factor family. Proc Natl Acad Sci USA 87:8060-8064.

Kaplan DR, Martin ZD, Parada LF (1991) Tyrosine phosphorylation and tyrosine kinase activity of the trk proto-oncogene product induced by NGF. Nature 350:158-160.

Klein R, Martin-Zanca D, Barbacid M, Parada LF (1990) Expression of the tyrosine kinase receptor gene trkB is confined to the murine embryonic and adult nervous system. Development 109:845-850.

Klein R, Jing SQ, Nanduri V, O'Rourke E, Barbacid M (1991a) The trk proto-oncogene encodes a receptor for nerve growth factor. Cell 65:189-197.

Klein R, Nanduri V, Jing SA, Lamballe F, Tapley P, Bryant S, CordonCardo C, Jones KR, Reichardt LF, Barbacid M (1991b) The trkB tyrosine protein kinase is a receptor for brain-derived neurotrophic factor and neurotrophin-3. Cell 66:395-403.

Knusel B, Beck KD, Winslow JW, Rosenthal A, Burton I.F, Widmer HR, Nikolics K, Hefti F (1992) Brain-derived neurotrophic factor administration protects basal forebrain cholinergic but not nigral dopaminergic neurons from degenerative changes after axotomy in the adult rat brain. J Neurosci 12:4391-4402.

Koliatsos VE, Clatterbuck RE, Winslow JW, Cayouette MH, Price DL (1993) Evidence that brain-derived neurotrophic factor is a trophic factor for motor neurons in vivo. Neuron 10:359-367.

Korsching S (1993) The neurotrophic factor concept: a reexamination. J Neurosci 13:2739-2748.

Lamballe F, Klein R, Barbacid M (1991) trkC, a new member of the trk family of tyrosine protein kinase, is a receptor for neurotrophin3. Cell 66:967-979.

Lärkfors L, Ebendal T, Lindsay RM, Alderson RF (1993) Effects of neurotrophins on rat embryonic cerebellar purkinje cells in vitro. Soc Neurosci Abstr 19:A278.14.

Lefebvre PP, Malgrange B, Staecher H, Moghadass M, Van De Water TR, Moonen G (1994) Neurotrophins affect survival and neuritogenesis by adult injured auditory neurons in vitro. Neuroreport 5:865-868.

Leibrock J, Lottspeich F, Hohn A, Hofer M, Hengerer B, Masiakowski P, Thoenen H, Barde YA (1989) Molecular cloning and expression of brain-derived neurotrophic factor. Nature 341:149-152.

Levi-Montalcini R (1987) The nerve growth factor: thirty-five years later. EMBO J 6:1145-1154.

Maisonpierre PC, Belluscio I, Squinto $S$, Ip NY, Furth ME, Iindsay RM, Yancopoulos GD (1990) Neurotrophin-3: a neurotrophic factor related to NGF and BDNF. Science 247:1446-1451. 
Mollman JE (1990) Cisplatin neurotoxicity. N Engl J Med 322:126127.

Nakai Y, Konishi K, Chang KC, Ohashi K, Morisaki N, Minowa Y, Morimoto A (1982) Ototoxicity of the anticancer drug cisplatin. Acta Otolaryngol (Stockh) 93:227-232.

Pirvola U, Ylikoski J, Palgi J, Lehtonen E, Arumäe U, Saarma M (1992) Brain-derived neurotrophic factor and neurotrophin 3 mRNAs in the peripheral target fields of developing inner ear ganglia. Proc Natl Acad Sci USA 89:9915-9919.

Roelofs RI, Hrushesky W, Rogin J, Rosenberg L (1984) Peripheral sensory neuropathy and cisplatin chemotherapy. Neurology 34:934938.

Rosenthal A, Goeddel D, Nguyen T, Lewis M, Shih A, Laramee GR, Nikolics K, Winslow JW (1990) Primary structure and biological activity of a novel human neurotrophic factor. Neuron 4:767-773.

Schecterson LC, Bothwell M (1994) Neurotrophin and neurotrophin receptor mRNA expression in developing inner ear. Hear Res 73:92100.

Shelton DL, Sutherland J, Gripp J, Camertato T, Armanini MP, Phillips HS, Carroll K, Spencer SD, Levinson AD (1995) Human trks: molecular cloning, tissue distribution, and expression of extracellular domain immunoadhesins. J Neurosci 15:477-491.

Siegal T, Haim N (1990) Cisplatin-induced peripheral neuropathy. Cancer 66:1117-1123.

Snider WD (1994) Functions of the neurotrophins during nervous system development: what the knockouts are teaching us. Cell 77:627638.

Soppet D, Escandon E, Maragos J, Middlemas DS, Reid SW, Blair J, Burton LE, Stanton BR, Kaplan DR, Hunter T, Nikolics K, Parada LF (1991) The neurotrophic factors brain-derived neurotrophic factor and neurotrophin -3 are ligands for the trkB tyrosine kinase receptor. Cell 65:895-903.

Squinto SP, Stitt TN, Aldrich TH, Davis S, Bianco SM, Radziejewski C, Glass DJ, Masiakowski P, Furth ME, Valenzuela DM, DiStefano PS, Yancopoulos GD (1991) trkB encodes a functional receptor for brain-derived neurotrophic factor and neurotrophin-3 but not nerve growth factor. Cell 65:885-893.

Stadnicki SW, Fleischman RW, Schaeppi U, Merriam P (1975) Cis- dichlorodiammineplatinum (II) (NSC-1 19875): hearing loss and other toxic effects in rhesus monkeys. Cancer Chemother Rep 59:467-480.

Thompson SW, Davis LE, Kornfeld M, Hilgers RD, Standefer JC (1984) Cisplatin neuropathy. Cancer 54:1269-1275.

Tsoulfas P, Soppet D, Escandon E, Tessarollo L, Mendoza-Ramirez J-L, Rosenthal A, Nikolics K, Parada LF (1993) The rat trkC locus encodes multiple neurogenic receptors that exhibit differential response to neurotrophin-3 in PC12 cells. Neuron 10:975-990.

Valenzuela DM, Maisonpierre PC, Glass DJ, Rojas E, Nunez L, Kong Y, Gies DR, Stitt TN, Ip NY, Yancopoulos GD (1993) Alternative forms of rat TrkC with different functional capabilities. Neuron 10: 963-974.

Vazquez E, Van De Water TR, Del Valle M, Veta JA, Staecker H, Giráldez F, Represa J (1994) Pattern of trkB protein-like immunoreactivity in vivo and the in vitro effects of brain-derived neurotrophic factor (BDNF) on developing cochlear and vestibular neurons. Anat Embryol (Berl) 189:157-167.

Verdi JM, Birren SJ, Ibanez CF, Persson H, Kaplan DR, Benedett M, Chao MV, Anderson DJ (1994) p75 ${ }^{\text {LNGRR }}$ regulates Trk signal transduction and NGF-induced neuronal differentiation in MAH cells. Neuron 12:733-745.

von Bartheld CS, Patterson SL, Heuer JG, Wheeler EF, Bothwall n Rubel EW (1991) Expression of nerve growth factor (NG tors in the developing inner ear of chick and rat. Developn $455-470$.

Weskamp G, Reichardt LF (1991) Evidence that biological a NGF is mediated through a novel subclass of high affinity 1 Neuron 6:649-663.

Wheeler EF, Bothwell M, Schecterson LC, Von Bartheld C: Expression of BDNF and NT-3 mRNA in hair cells of the Corti: Quantitative analysis in developing rats. Hear Res 73

Yan Q, Elliott JL, Snider WD (1992) Brain-derived neurotrop rescues spinal motoneurons from axotomy induced cell deat 360:753-755.

Yan Q, Matheson C, Sun J, Radeke MJ, Feinstein SC, Miller J Distribution of intracerebral ventricularly administered neur in rat brain and its correlation with Trk receptor express Neurol 127:23-36.

Ylikoski J, Pirvola U, Moshnyakov M, Palgi J, Arumae U, S (1993) Expression patterns of neurotrophin and their rec RNAs in the rat inner ear. Hear Res 65:69-78. 